\title{
Market Structure in the Vietnamese banking system: a non-structural approach ${ }^{1}$
}

\author{
Roman Matousek \\ School of Business, Management and Economics, Sussex University \\ Thao Ngoc Nguyen ${ }^{2}$ \\ Nottingham Business School, Nottingham Trent University \\ Chris Stewart \\ School of Economics, History and Politics, Kingston University
}

\begin{abstract}
This paper examines the market structure of Vietnam's banking sector during 1999-2009, which is after the introduction of the two-tier banking system, using the non-structural (Panzar-Rosse) model. We consider a more comprehensive range of specifications, in terms of a greater number of environmental covariates and different dependent variables, than in previous applications of this model. Further, this is the first study that uses lagged input prices (to avoid endogeneity), excludes assets (to avoid specification bias) and includes a lagged dependent variable (to avoid dynamic panel bias) in such a study of the Vietnamese banking system. We find that the Vietnamese banking system operates in monopoly.
\end{abstract}

Keywords: Banking; Bank regulation; Central bank, Bank performance. JEL classification: $\mathrm{C} 23, \mathrm{G} 21, \mathrm{~L} 22$

\footnotetext{
${ }^{1}$ We are grateful to José Sanchez Fung for his helpful comments and suggestions on an earlier draft of the paper.

2 Corresponding author: Thao Ngoc Nguyen, Nottingham Business School, Nottingham Trent University, Burton street, Nottingham NG1 4BU, Email: thao.nguyen@ntu.ac.uk or nnthao2k6@yahoo.com, Tel: +44 (0) 1158483878.
} 


\section{Introduction}

In this paper, we provide a detailed analysis of the degree of market competition in the Vietnamese banking system using the Panzar and Rosse (1987) non-structural model. This model suggests that the market is a monopoly if the service offered by a particular bank is independent and originate. In contrast, the market is competitive if bank services are similar in the market. We apply the non-structural model to an extensive panel data set of 48 Vietnamese commercial banks, which includes state owned commercial banks and non-state owned commercial banks, from 1999 to 2009 . Using this procedure we consider whether the Vietnamese banking market is best characterised by monopoly, perfect competition or the intermediate case of monopolistic competition.

We estimate $\mathrm{H}$-statistics of models that both include assets and exclude assets with current or lagged input prices. We also estimate E-statistics to test whether the long-run equilibrium conditions required for the H-statistics to be valid hold when using the fixed-effects estimator within the equilibrium approach. A comparison of models using current and lagged input prices is employed to assess whether input prices are endogenous. This is the first study that uses lagged input prices (to avoid endogeneity) and excludes assets (to avoid bias) in a study of the Vietnamese banking system. This study also extends the previous literature (Bikker et al., 2006a, 2006b and Bikker and Spierdijk, 2009) by considering new additional variables such as total assets, capital/assets, loans/deposits and the number of branches in the model's specification. In addition, we compare inference using four alternative dependent variables being revenue/assets, interest income/assets, revenue and interest income. However, the main contribution of this paper is to determine the market structure in the recent period after the Vietnamese banking system has transformed into a less centralised two-tier system. Our study is the first to uniquely identify the market structure of this developing economy's banking system (using data only for Vietnam and not observations from other countries) in a post-transition period. ${ }^{3}$ Another novelty of the paper is to assess the biases that arise from model misspecification, in particular, biases dues to endogeneity, including assets and not accounting for a potential dynamic specification.

The rest of this paper is organised as follows: section 2 deals with developments in the Vietnamese banking system in the period from 1986 to 2009; section 3 provides a literature review of the non-

\footnotetext{
${ }^{3}$ The few previous studies that have sought to determine Vietnam's market structure have done so in an earlier period when less of the transition had taken place and have assumed homogeneity of the Vietnamese banking system's market structure with the other countries analysed.
} 
structural model in banking; section 4 discusses methodology and data; section 5 presents our empirical results, and section 6 concludes.

\section{The Vietnamese banking system during 1986-2009}

From 1986 to 2009 the Vietnamese banking system was transformed from a mono to two-tier banking system. The two-tier banking system has the State Bank of Vietnam (SBV) as the central bank (tier 1) and four specialised state owned banks (tier 2). Table 1 shows the number of Vietnamese commercial banks from 1990 to 2009. With extended networks in almost all provinces and larger cities, state owned commercial banks have a competitive edge in providing banking services. Although joint stock commercial banks increased their numbers immediately after their appearance in 1990 (in 2009 there were 37 joint stock commercial banks), the leading positions in the market still belong to state owned commercial banks. State owned commercial banks were originally sector departments under the State Bank of Vietnam, with specified lending programmes to state owned enterprises which were based on government policies.

Non-state owned commercial banks consist of joint stock commercial banks, branches of foreign banks, joint venture commercial banks and foreign commercial banks ${ }^{4}$. Unlike state owned commercial banks a number of joint stock commercial banks make profits due to good performance. Joint stock commercial banks have achieved average returns on equity between 15 per cent and 30 per cent. Being less than 15 years old joint stock commercial banks are relatively young and they can be divided into three groups: (1) the top five large urban banks; (2) a smaller group of banks that are either growing rapidly or have established a niche; and (3) 12 small rural joint stock commercial banks. The top five urban banks are Techcombank, Sacombank, VIBBank, Asia Commercial Bank, and East Asia Commercial Bank. The smaller urban joint stock commercial banks include Viet A Bank and Saigon Bank. Small rural commercial banks were all transformed into city commercial banks at the end of 2010, such as An Binh Bank and Saigon-Hanoi Bank. These banks developed throughout the country, not just in rural areas and with help from big business and foreign investors they also performed well in the 2000s. The number of branches of foreign banks increased from 18 banks in 1995 to 48 banks in 2009. However, each foreign

\footnotetext{
${ }^{4}$ Foreign commercial banks normally transformed out of branches of foreign banks. Data on assets, loans and deposits of branches of foreign banks are very small compared to other banks. Therefore, in our application non-state owned commercial banks consist of joint stock commercial banks, joint venture commercial banks and one foreign commercial bank.
} 
bank normally has one branch in either Hanoi or Ho Chi Minh City. Hence, their assets, loans and deposits are very small compared to state owned commercial banks, joint stock commercial banks and joint venture commercial banks. Despite Foreign Direct Investment in US dollar terms growing by a factor of eight between 1990 and 2005, foreign companies are still hesitant as whether or not to choose domestic banks when they enter this new market. The number of joint venture commercial banks has increased slightly from four to six banks between 1995 and 2009. The first foreign commercial bank (being HSBC) had a license to set up a wholly foreign-owned bank from 2008 (see Nguyen and Stewart, 2013).

Table 2 shows data on loans, assets, deposits, capital and non-performing loans of the Vietnamese banking system (state owned commercial banks and non-state owned commercial banks) from 1999 to 2009. On the whole, there was an increasing trend of loans, assets, deposits and capital over the period. Vietnamese banks were burdened by a high volume of non-performing loans, particularly during the 1990s, however, these generally decreased from 1999 to 2009. Non-performing loans of non-state owned commercial banks are typically lower than those of state owned commercial banks.

In terms of regulation, the State Bank of Vietnam aims to create a banking supervision development (following Basel) from 2010 onwards. Meanwhile, the coverage, measures and procedures of banking supervision and monitoring are to be reformed in accordance with the development of internet technologies and banking technology. This will be done by applying key principles of international standards on banking supervision (Basel I and Basel II). The old capital adequacy ratio standards for banks in Basel I and Basel II are 8 per cent and 12 per cent, respectively. The capital adequacy ratio for the Vietnamese commercial banks is to be adjusted to 9 per cent (as Circular No. 13/TT-NHNN dated $20^{\text {th }}$ May 2010 of the State Bank of Vietnam).

In parallel with the speed of the country's economic development, the loan growth rate rose dramatically. One of the reasons was that many banks had greatly increased their credit growth through real estate loans, due to the over-heating of the real estate market. The credit growth rate of the banking system increased to nearly 38 per cent in 2007 and peaked at an alarming 63 per cent in the first quarter of 2008 (WB, 2008: 3). This has been the highest growth rate within the past decade. When the inflation rate and trade balance deficit had become more serious, the government applied a traditional tightening of monetary policy in order to reduce money supply circulation, which affected the banking system. Compulsory measures were necessary for banks to reorganise and strengthen their organisations. 


\section{Literature review}

Empirical studies that use the non-structural model to establish the extent of contestability in banking markets are concerned with drawing inferences about market structure indirectly from observing conduct. This is because of contestability, which depends on the extent of potential competition, is not observable directly (Goddard et al., 2001). Panzar and Rosse (1987) formulated simple models for monopolistic, oligopolistic and perfectly competitive markets, and develop a test to discriminate between these market structures. Bikker and Bos (2008) explained this non-structural model as based on the properties of a reduced-form revenue equation at the firm or bank level and using the $\mathrm{H}$-statistic, which, under certain assumptions, can serve as a measure of how competitive banks are. The test is from a general banking model, which determines equilibrium output and the equilibrium number of banks by maximizing profits at both the bank level and the industry level. This implies, first, that bank $\mathrm{i}$ maximises its profits, where marginal revenue equals marginal cost. The profit maximising condition is:

$R_{i}^{\prime}\left(Y_{i}, n, Z_{i}\right)-C^{\prime}{ }_{i}\left(Y_{i}, n, T_{i}\right)=0$

$R_{i}$ refers to revenue, $C_{i}$ to cost, $Y_{i}$ to output, $w_{i}$ to a vector of $m$ factor input prices, and $Z_{i}$ and $T_{i}$ to vectors of exogenous variables that shift the bank's revenue and cost functions, respectively. The sub index i refers to bank $\mathrm{i} ; \mathrm{n}$ is the number of banks; and the prime symbol denotes a first derivative with respect to output. Second, at the market level, it means that, in equilibrium, the zero supernormal profit constraint holds:

$R^{*}{ }_{i}\left(Y^{*}, n^{*}, Z_{i}\right)-C^{*}\left(Y^{*}, w_{i}, T_{i}\right)=0$

Variables marked with an asterisk $(*)$ represent equilibrium values. Market power is measured by the extent to which a change in factor input prices $\left(d w_{k, i}\right)$ for $k=1, \ldots, m$ is reflected in changes in equilibrium revenue $\left(d *_{i}\right)$, earned by bank $i$ (where $m$ denotes the number of input prices). Panzar and Rosse (1987) defined a measure of competition $\mathrm{H}$ as the sum of the elasticities of the reduced-form revenue function with respect to factor prices:

$$
H=\sum_{k=1}^{m}\left(\frac{\partial R_{i}^{*}}{\partial w_{k, i}}\right)\left(\frac{w_{k, i}}{R_{i}^{*}}\right)
$$


The first market model that Panzar and Rosse investigate is a monopoly. In their analysis, monopoly includes the case of price-taking competitive banks, as long as the prices they face are truly exogenous, that is, as long as their equilibrium values are unaffected by changes in the other exogenous variables in the model. The empirical refutation of monopoly constitutes a rejection of the assumption that the revenue of the banks in question is independent of the decisions made by their actual or potential rivals. The Panzar and Rosse model demonstrates that under monopoly, an increase in input prices will increase marginal costs, reduce equilibrium output and subsequently reduce revenue; hence $\mathrm{H}$ will be zero or negative. In the case of monopolistic competition, the analysis is based on the comparative static properties of the Chamberlain equilibrium model. In the equilibrium condition, interdependence affects the structural revenue function, and the bank's profit finally becomes zero as the conditions of entry and withdrawal are unlimited; hence $\mathrm{H}$ will be smaller than one. In the case of perfect competition, under certain conditions both marginal cost and average cost increase without changing the optimum amount of the individual bank's output. If this condition occurs and some banks withdraw from the market, the remaining banks would individually face increased demand. This increased demand leads to higher prices and revenue, which is equal to the increase of cost, and $\mathrm{H}$ will become one. In summary:

- $\quad \mathrm{H} \leq 0$ : indicates a monopoly.

- $0<\mathrm{H}<1$ : indicates the intermediate case of monopolistic competition.

- $\quad \mathrm{H}=1$ : indicates a perfectly competitive industry.

Shaffer (1982) obtained $0<\mathrm{H}<1$ for a sample of unit banks in the New York banking sector, suggesting monopolistic competition. Nathan and Neaven (1989) confirmed this result for New York banks even when the effect of loan losses is considered. Nathan and Neaven (1989) tested for contestability for a group of Canadian banks, trust companies and mortgage companies with data for the period from 1982 to 1984 . The result indicated $0<\mathrm{H}<1$. DeBandt and Davis (2000) provided a significant improvement on the specification of variables employed in the model and its functional form. They emphasised that the banking industry is not a general industry, like manufacturing, rather it is an industry with individual characteristics, which is in line with the argument of Panzar and Rosse (1987). They obtained $0<\mathrm{H}<1$ for France, Germany, Italy and the US. Competition appears to be most intense in the US while small banks are found to enjoy some monopoly power in the German and French markets. 
The model used for calculating the $\mathrm{H}$-statistic has taken a variety of specific forms in the general banking literature. Molyneux et al. (1994) and Bikker and Groeneveld (2000) employed the ratio of interest revenue to the total balance sheet as an endogenous variable. Molyneux et al. (1994) investigated major European banking markets between 1986 and 1989 and they suggested that banks in Germany, the UK, France and Spain were in monopolistic competition during this period whereas banks in Italy behave as if in monopoly. Bikker and Groeneveld (2000) used data on 892 banks from 15 EU countries over the sample period 1989-1996. Their results show that European banking sectors operate under conditions of monopolistic competition. On the other hand, Nathan and Neave (1989) used the logarithm of interest revenue as the dependent variable. According to DeBandt and Davis (2000), this is the most appropriate measure since the ratio of interest revenue to total assets might be interpreted as yielding a price equation rather than a revenue function. However, homogeneity might be induced even in the logarithmic specification. DeBandt and Davis (2000) insisted that in empirical studies on banking competition, although cross-sectional results are generally employed, the implicit assumption is that all banks have access to the same factor market and only the scale of operations differ. They argued that the dimension of the time-series is crucial, and that irregular results might arise from estimating a crosssectional regression of the equation with Ordinary Least Squares for every year $(t=1, \ldots T)$. As a result, they asserted that it is desirable to focus on the pooled sample regression.

In Vietnam, three previous studies have applied the Panzar-Rosse model to the Vietnamese banking system. Bikker et al. (2006a, 2006b) and Bikker and Spierdijk (2009) analysed bank structure in the world (with 101 countries including Vietnam) from 1986-2004. Due to data constraints, they only investigated banking structure in Vietnam from 1991 to 2004 for 24 banks. ${ }^{5}$ They calculated the H-statistic for the Vietnamese banking system as $\mathbf{0 . 7 4}$. However, they applied only one model for all 101 countries, including Vietnam, and this model did not reflect the actual business in Vietnam where state owned commercial banks still dominate the whole banking system. Further, they could not observe the three input prices directly. Therefore, they used the ratio of annual personal expenses to total assets as an approximation for the price of personal expenses, and the ratio of other non-interest expenses to fixed assets as a proxy for the price of capital expenditure. Moreover, Bikker et al. (2006a, 2006b) and Bikker and Spierdijk (2009) preferred interest income as the dependent variable, while other researchers, such

\footnotetext{
${ }^{5}$ The total number of observations for Vietnam that they use is only 135 whereas our maximum sample size is 376 observations.
} 
as Nathan and Neave (2001), favour using revenue in the Panzar-Rosse model. Hence, for comparison purposes we will use both interest income and revenue as dependent variables in this paper.

Our data set includes 48 Vietnamese commercial banks over the period 1999 to 2009 . This is the first time that such an extensive panel data set has been employed to uniquely identify the Vietnamese banking system's market structure using the non-structural model (our maximum sample period is 376 observations). No previous study has used lagged input prices (to avoid endogeneity) and excluded assets (to avoid bias) in a study of the Vietnamese banking system. Environmental factors such as total assets, capital/assets, loans/deposits and the number of branches are incorporated in our models and have not all been employed in previous studies of Vietnam. In addition, for comparative purposes, we use the following four different dependent variables: revenue divided by total assets (REV/TA); interest income divided by total assets (INT/TA); revenue (REV); and interest income (INT). We use the nonstructural model to determine whether the Vietnamese banking system is best characterised by monopoly, monopolistic competition or perfect competition.

\section{Methodology and data}

\subsection{Calculating H-statistics}

We estimate non-structural models based on the Panzar-Rosse specification using the following empirical form:

$$
L N\left(R O A_{i, t}\right)=\delta_{0}+\delta_{1} L N\left(\frac{P E_{i, t}}{T E_{i, t}}\right)+\delta_{2} L N\left(\frac{I E_{i, t}}{F F_{i, t}}\right)+\delta_{3} L N\left(\frac{C E_{i, t}}{F A_{i, t}}\right)+\delta_{4} \frac{T C_{i, t}}{T A_{i, t}}+\delta_{5} \frac{C L_{i, t}}{C D_{i, t}}+\delta_{6} L N\left(T A_{i, t}\right)+\delta_{7} L N\left(B R_{i, t}\right)
$$

where, $L N\left(R_{0} A_{i, t}\right)$ is bank i's revenue, which is initially measured in two ways: the natural logarithm of revenue divided by total assets $L N\left(\frac{R E V_{i, t}}{T A_{i, t}}\right)$ and the natural logarithm of interest income divided by total assets $L N\left(\frac{I N T_{i, t}}{T A_{i, t}}\right)$. Also included is $L N\left(\frac{P E_{i, t}}{T E_{i, t}}\right)$ the natural logarithm of the unit price of labour, $\frac{\text { PersonalExpenses }}{\text { TotalEmployees }} ; \quad L N\left(\frac{I E_{i, t}}{F F_{i, t}}\right)$, the natural logarithm of the unit cost of funds, $\frac{\text { InterestExpenses }}{\text { FundableFunds }}$; 
$L N\left(\frac{C E_{i, t}}{F A_{i, t}}\right)$ the natural logarithm of the unit cost of fixed assets, $\frac{\text { CapitalExpenses }}{\text { FixedAssets }}$ (see Claessens and Laeven, 2004; Gelos and Roldos, 2004: 50 and Nathan and Neave, 2001: 580). $\frac{T C_{i, t}}{T A_{i, t}}$ is the capital to assets ratio; $\frac{C L_{i, t}}{C D_{i, t}}$ is the loans to deposits ratio; $\mathrm{LN}\left(\mathrm{TA}_{\mathrm{i}, \mathrm{t}}\right)$ is the natural logarithm of total assets and $\mathrm{LN}\left(\mathrm{BR}_{\mathrm{i}, \mathrm{t}}\right)$ is the natural logarithm of the number of branches.

The H-statistic, which is used to determine the degree of competition, is calculated from (4) using:

$H=\delta_{1}+\delta_{2}+\delta_{3}$

From equation (5), if $\mathrm{H} \leq 0$ the market is a monopoly, if $0<\mathrm{H}<1$ the market is in monopolistic competition and if $\mathrm{H}=1$ the market is in perfect competition.

\subsection{Models with and without assets}

Many previous empirical studies include among the controls the log of assets, $L N\left(T A_{i, t}\right)$, to measure size or some other similarly defined measure of bank size; and many studies also scale the dependent variables with total assets, that is: $L N\left(\frac{R E V_{i, t}}{T A_{i, t}}\right)$ and $L N\left(\frac{I N T_{i, t}}{T A_{i, t}}\right)$. However, Bikker et al. (2006a) pointed out that it is incorrect to estimate a revenue elasticity using a specification that includes a quantity-type variable among the controls, or using a specification which, through rescaling, converts a revenue variable into a price-type variable. In fact, if $L N\left(T A_{i, t}\right)$ appears among the controls, then it is immaterial whether the dependent variable is unscaled (not divided by total assets) or scaled (divided by total assets). In either case, the coefficients on the factor input prices $\left(\delta_{1}, \delta_{2}, \delta_{3}\right)$ should be interpreted as output price elasticities and not as revenue elasticities. The model is misspecified if assets are included and inference regarding market structure is invalid. Hence, on the left-hand side of the models, the dependent variables should be $L N\left(R E V_{i, t}\right)$ and $L N\left(I N T_{i, t}\right)$ instead of $L N\left(\frac{R E V_{i, t}}{T A_{i, t}}\right)$ and $L N\left(\frac{R E V_{i, t}}{T A_{i, t}}\right)$, respectively. Further, $L N\left(T A_{i, t}\right)$ should be removed from the right-hand side of the models (Goddard 
and Wilson, 2009). ${ }^{6}$ The valid unscaled model (that we also estimate) is obtained from (4) with $\delta_{6}=0$ and using the unscaled dependent variables, $L N\left(R E V_{i, t}\right)$ and $L N\left(I N T_{i, t}\right)$.

\subsection{Calculating E-statistics (testing equilibrium)}

For the $\mathrm{H}$-statistic to be a valid test it must be calculated on observations that are in long-run equilibrium. This suggests that competitive capital markets will equalise risk-adjusted rates of return across banks such that, in equilibrium, rates of returns should not be significantly correlated with input prices (Classens and Laeven, 2004; Lloyd-Williams et al., 1994; Matthews et al., 2007; Molyneux and Forbes, 1995 and Shaffer, 1982). Thus, in the context of the theory of competitiveness and contestability set out in (4) we specify a model for the determination of whether equilibrium holds. This is obtained by replacing the dependent variable in (4) with profit before tax on assets (1+PBT/TA) thus: ${ }^{7}$

$L N\left(1+\frac{P B T_{i, t}}{T A_{i, t}}\right)=\gamma_{0}+\gamma_{1} L N\left(\frac{P E_{i, t}}{T E_{i, t}}\right)+\gamma_{2} L N\left(\frac{I E_{i, t}}{F F_{i, t}}\right)+\gamma_{3} L N\left(\frac{C E_{i, t}}{F A_{i, t}}\right)+\gamma_{4} \frac{T C_{i, t}}{T A_{i, t}}+\gamma_{5} \frac{C L_{i, t}}{C D_{i, t}}+\gamma_{6} L N\left(T A_{i, t}\right)+\gamma_{7} L N\left(B R_{i, t}\right)$

A version of (6) without $L N\left(T A_{i, t}\right)$ is also estimated by setting $\gamma_{6}=0$.

The E-statistic that is used for testing whether the market is in equilibrium is defined as:

$E=\gamma_{1}+\gamma_{2}+\gamma_{3}$

We test whether $E=0$ using an F-test. If rejected, the market is not in equilibrium (Claessens and Laeven, 2004), whereas if $E=0$ the market is in equilibrium and the H-statistic calculated using (4) and (5) is valid.

\subsection{Models with current and lagged input prices}

Simultaneity is a dual direction of causality in a system of equations which violates the assumption that the explanatory variables and equation's error term are uncorrelated. Variables in a regression can

\footnotetext{
${ }^{6}$ In this study, we estimate models that both include and exclude assets for comparison purposes.

${ }^{7}$ Because profit before tax can take on small (negative) values, we compute the dependent variable as (1+PBT/TA).
} 
violate this assumption for several reasons, including omitted variable bias, measurement error and simultaneity/reverse causation. In our regression, the models including the current values of input prices might suffer from simultaneity (endogeneity) bias between input prices and the dependent variables (revenue and interest income). We assess whether or not one or more of the input prices (LN(IE/FF), LN(PE/TE) and LN(CE/FA)) suffers from endogeneity by comparing regressions that include current input prices and regressions that include lagged input prices - see Shaffer (2004) and Goddard and Wilson (2009). To obtain models using lagged input prices the current price variables are replaced by their values lagged one time period in (4) and (6). Large differences in the estimated coefficients (and therefore $\mathrm{H}$-statistics and E-statistics) using models with current input prices and using models with lagged input prices is taken as an indication of the endogeneity. If endogeneity appears evident inference from models that incorporate lagged input prices is preferred.

\subsection{Model estimation}

Econometric problems may arise from estimating equation (4) using panel data including the process being dynamic, with current realisations of the dependent variable being influenced by its past values, and that the idiosyncratic disturbances may have individual-specific patterns of heteroscedasticity and serial correlation. To address these issues a generalised method of moments (GMM) estimator, such as that introduced by Arellano and Bond (1991) and those discussed by Roodman (2009), may be used when lagged dependent variables are added. The difference and system GMM estimators can be applied using either the one-step method or the two-step method.

After experimentation to find a valid specification we report the results from the one-step system GMM estimator with heteroscedasticity and autocorrelation robust coefficient standard errors (results from the other estimators are available upon request).

The pooled OLS and fixed-effects estimators applied to a model that includes a lagged dependent variable and that should allow for cross-sectional fixed-effects have the following properties. The (pooled) OLS estimator that excludes fixed-effects will be inconsistent when $\mathrm{T}$ is small (even when $\mathrm{N}$ is 
large) and the lagged dependent variable's coefficient will be upwards biased. ${ }^{8}$ The fixed-effects estimator will also be inconsistent when T is small and there is a downward bias in the lagged dependent variable's coefficient. Since the bias on the lagged dependent variable for the pooled OLS and fixedeffects estimators are in the opposite direction we expect the true coefficient on the lagged dependent variable to fall in between these two estimators' values. ${ }^{9}$

When using GMM, Hansen's J-statistic is employed to assess whether the instruments are exogenous whilst allowing for heteroscedastic and autocorrelated disturbances. ${ }^{10}$ Since this test is biased towards accepting that the instruments are exogenous as the number of instruments increases we follow Roodman's (2009) recommendation and ensure that the number of instruments is less than the number of cross-sections in the panel to help guard against this potential problem.

\subsection{Data}

In this paper, annual individual balance sheets and income statements of 48 Vietnamese commercial banks from 1999 to 2009 have been collected from the State Bank of Vietnam, National Library of Vietnam and individual banks. Although the number of banks for which there is data is only half of the total in the Vietnamese banking system they account for more than 90 per cent of total customer loans, total customer deposits and total assets. ${ }^{11}$

\section{Empirical results}

Table 3 reports the non-structural model estimated for the full sample using the fixed-effects estimator. The results include estimated revenue equations (in the column headed "H-statistics") and profit

\footnotetext{
${ }^{8}$ The GMM estimators assume small $\mathrm{T}$ and large $\mathrm{N}$ in the panel. Hence, the GMM estimators are consistent as $\mathrm{N}$ tends to infinity and not as $\mathrm{T}$ tends to infinity. When $\mathrm{T}$ is large, dynamic models using the pooled OLS or fixed-effects estimators are consistent meaning that there is little benefit from using GMM (which can become unreliable when T is large due to the overfitting of endogenous variables).

${ }^{9}$ In our application T is small and we expect both the OLS and fixed-effects estimators to be biased.

${ }^{10}$ In the application of GMM, the Sargan test has a null hypothesis of "the instruments as a group are exogenous". Therefore, the higher is the p-value of the Sargan statistic the better the result is. In robust estimation, Stata reports the Hansen statistic instead of the Sargan test and both tests have the same null hypothesis. The Arellano - Bond test for autocorrelation has a null hypothesis of no autocorrelation and is applied to the differenced residuals. The test for $A R(2)$ in first differences is important because it will detect autocorrelation in levels. These models are valid when these tests' p-values are higher than 0.05 (see Roodman, 2009).

${ }^{11}$ Five of the 48 banks are state owned commercial banks, five are joint stock commercial banks, one is a foreign commercial bank and the remaining 37 are joint stock commercial banks. Several banks established in 2008 and 2009 are included in the data. The number of records ranged from a low of 17 banks in 1999 to a high of 46 in 2009. Banks also have differing frequencies of years in the data - see Table 1. There are 16 banks with data for all years; 12 banks with $4-8$ years of data; 14 banks with 5-7 years of data and five banks with 2-4 years of data (of which three banks were established in 2008 and one bank was founded in 2006). Only one bank (which was transformed from a branch of a foreign bank to a foreign commercial bank in 2008) has one year of data.
} 
equations (in the column headed "E-statistics") using all measures of the dependent variable with current or lagged input prices both with and without assets. $H_{0}^{1}$ refers to the F-test of the null hypothesis that cross-sectional fixed-effects are redundant. $H_{0}^{2}$ refers to the F-test of the null hypothesis that both cross-sectional and time-period fixed-effects are redundant. All of the F-tests reject the exclusion of cross-sectional and period fixed-effects, therefore, the '2-way-FE' model is favoured and reported in the table. ${ }^{12}$ We also report $R^{2}$, the adjusted $R^{2}\left(\operatorname{Adj} R^{2}\right)$, the statistic for testing the null hypothesis that $R^{2}=$ 0 (F-statistic) and the number of observations.

The $\mathrm{H}$-statistic is reported in the row labelled $\mathrm{H}$-sta. in the table. The $\mathrm{H}$-statistics are 0.59 (with $\mathrm{LN}(\mathrm{REV} / \mathrm{TA})$ as the dependent variable) and 0.62 (with LN(INT/TA)) in the models with assets and with current input prices. The rows below the $\mathrm{H}$-statistics show the result of t-tests for the null hypotheses that $\mathrm{H}=0$ and $\mathrm{H}=1$. The $\mathrm{H}$-statistics are significantly different from both zero and one in these models. When the H-statistic is between zero and one (as in this case), it indicates monopolistic competition. In the models without assets and with current input prices the $\mathrm{H}$-statistics are 0.96 for the equation where $L N(R E V)$ is the dependent variable and 0.98 for the specification with $L N(I N T)$ as the regressand. They are both significantly different from zero and insignificantly different from one. Since $H \cong 1$ this indicates that the Vietnamese banking system is a competitive industry. ${ }^{13}$ Comparing the models with and without assets we notice that excluding total assets from the revenue equations has transformed our inference of the Vietnamese banking market from monopolistic competition to perfect competition. This is consistent with the prediction of Bikker et al. (2006a) and Goddard and Wilson (2009) because the downward bias in $\mathrm{H}$ is removed when assets are excluded.

In the models with assets and with lagged input prices, the $\mathrm{H}$-statistic is 0.16 when LN(REV/TA) is the dependent variable and 0.13 when $\mathrm{LN}(\mathrm{INT} / \mathrm{TA})$ is the regressand. The null hypotheses that the $\mathrm{H}$-statistic is zero or one are both rejected. This indicates that the industry is in monopolistic competition, if close to monopoly. Lastly, the $\mathrm{H}$-statistics based upon revenue equations excluding assets that include lagged input prices as regressors are 0.45-0.43 (both are significantly different from zero and one, indicating monopolistic competition). Once again the models including assets have notably lower $\mathrm{H}$-statistics than those excluding assets, this likely reflects the specification bias arising from the inclusion of assets.

\footnotetext{
12 '2-way-FE' incorporates both cross-sectional and period fixed-effects.

${ }^{13} \mathrm{An}$ increase in costs causes some banks to exit, prices to increase, and the revenue of the survivors to rise at the same rate as the increase in costs.
} 
Further, these $\mathrm{H}$-statistics are notably smaller than the corresponding equations that use current input prices, being $0.96-0.98$. This difference is most likely due to simultaneity bias. ${ }^{14}$ Hence we favour the results using lagged input prices and without assets for inference and conclude that the Vietnamese banking system is in monopolistic competition.

Table 3 also shows the results of the profit equations and their E-statistics for the full sample (in the column headed "E-statistics"). The E-statistic is used to determine whether the long-term equilibrium condition of the market is met. If the E-statistic is equal to zero the market is in long-term equilibrium whereas when the E-statistic is not equal to zero the market is not in long-term equilibrium. If the market is not in equilibrium the value of the $\mathrm{H}$-statistic (obtained from the corresponding revenue equation) is temporal and the degree of competitiveness is changing through time. In this case, the estimated models are not valid for inference and it is appropriate to employ a dynamic model to determine the equilibrium value of the market. We use the '2-way-FE' specification for inference because both crosssection and time-period fixed-effects are jointly significant according to the $H_{0}^{1}$ and $H_{0}^{2}$ F-tests. The Estatistic in the '2-way-FE' models are 0.007 (with assets and with current input prices), 0.006 (without assets and with current input prices), 0.007 (with assets and with lagged input prices) and 0.003 (without assets and with lagged input prices). In all cases, the null hypothesis that the Vietnamese banking system is in equilibrium is not rejected. Hence, all the corresponding $\mathrm{H}$-statistics are valid. Due to simultaneity bias in the models using current input prices and the misspecification of the models that include assets (see, Bikker et al., 2006a; Goddard and Wilson, 2009) we favour the model without assets and with lagged input prices. Hence, the Vietnamese banking system is in long-run equilibrium $(E \cong 0.003)$ and characterised by monopolistic competition $(H \cong 0.43-0.45$ ) during the period 1999 to 2009 .

We also note the following findings from the favoured models estimated over the full sample. The unit cost of funds (LN(IE/FF)) is positive and significant at the one per cent level for both dependent variables. The unit price of labour ( $\mathrm{LN}(\mathrm{PE} / \mathrm{TE}))$ is positive and significant at the 10 per cent level in the model where revenue is the dependent variable and insignificant when interest income is the regressand. The unit cost of fixed assets (LN(CE/FA)) is insignificant in the models with both dependent variables. These results suggest that the unit cost of funds has the most significant impact on revenue and interest

\footnotetext{
${ }^{14}$ Unreported results (that are available from the authors upon request) using the Wu-Hausman test broadly confirm that current input prices are unlikely to be weakly exogenous.
} 
income of the three input prices. These favoured specifications also indicate that customer loans over customer deposits (CL/CD) and total capital over total assets (TC/TA) are negative and significant while the number of branches $(\mathrm{LN}(\mathrm{BR}))$ is positive and significant.

Table 4 reports the revenue equations estimated using the one-step system GMM estimator (for models excluding assets and including lagged input prices) over the full sample period. Time period fixed effects are included in both models (because F-tests reject their exclusion for both models) however the statistics relating to these variables are not reported to save space. To investigate misidentifying restrictions, we employ the Hansen (Sargan) test which indicates the null hypothesis that the population moment conditions are correct is not rejected as $p=0.110>0.05$ (where $L N(R E V)$ is dependent variable) and $p=0.107>0.05$ (where $L N(I N T)$ is dependent variable). The test for first-order serial correlation (probability values are reported in the row labelled $A R(1)$ in Table 4) does not indicate whether the model is misspecified because first-order negative autocorrelation is expected when using panel GMM. Hence, our finding of evident first-order autocorrelation is expected and does not cause us to view either of the models given in Table 4 as invalid. We therefore follow conventional practice and focus on the test for second-order serial correlation to determine whether the model is valid or not (see Roodman, 2009). ${ }^{15}$ The probability value for the test for second-order serial correlation $(A R(2))$ is 0.715 in the model where revenue is dependent variable and 0.757 in the model where interest income is dependent variable indicating no evident autocorrelation. Hence, both models are considered valid for inference. Further, for both equations the lagged dependent variable is significant which indicates that these models estimated by GMM should be preferred to those using the fixed-effects estimators as reported in Table 3.

Goddard and Wilson (2009, pp. 2285 - 2286) provided simulation evidence that the difference GMM estimator of Arellano and Bond (1991), in a model with a lagged dependent variable, is better at identifying the $\mathrm{H}$-statistic compared to the fixed-effects estimator (in a model without a lagged dependent variable) when the true coefficient on the lagged dependent variable is greater than zero, which is the case in our study.

\footnotetext{
15 "To test for autocorrelation aside from the fixed effects, the Arellano-Bond test is applied to the residuals in differences. Because $\Delta v i t$ [the difference of the current period error term] is mathematically related to $\Delta v i, t-1$ via the shared $v i, t-1$ term, negative first-order serial correlation is expected in differences and evidence of it is uninformative. Thus to check for first-order serial correlation in levels, we look for second-order correlation in differences, on the idea that this will detect correlation between the vi,t-1 in $\Delta v i t$ and the vi,t-2 in $\Delta v i, t-2$. In general, we check for serial correlation of order / in levels by looking for correlation of order I+ 1 in differences." Roodman (2009, p. $119)$, our comments are given in squared parentheses.
} 
Our estimated $\mathrm{H}$-statistics based on the model estimated by fixed-effects (without assets and including lagged input prices) that imposes $\delta_{7}=0$ are reported in Table 3 as 0.453 and 0.430 . The H-statistics based on the Blundell and Bond (1998) system GMM estimator that allows $\delta_{7}>0$ are reported in Table 4 as -1.283 and -2.984 . We find that the fixed-effects estimates of the H-statistic are smaller in magnitude than the system GMM estimates, which is consistent with the bias predicted when $\delta_{7}>0$. Since our system GMM estimates of $\delta_{7}$ reported in Table 4 are 0.75 and 0.83 and are significantly different from zero and positive this suggests that we would expect such a bias (this assumes that Goddard and Wilson's (2009) results based on the difference GMM estimator are also valid for the system GMM estimator that we employ). That is, our results are consistent with the predictions of Goddard and Wilson (2009) in this respect.

Goddard and Wilson (2009, p. 2285) also showed, via simulation, that as the true value of $\delta_{7}$ approaches unity its difference GMM estimate becomes downward biased causing the $\mathrm{H}$-statistic to be downward biased in absolute value. This in turn causes the test for the null hypothesis that the $\mathrm{H}$-statistic is equal to one to be incorrectly sized. ${ }^{16}$ Our estimates of $\delta_{7}$ by system GMM reported in Table 4 are 0.75 and 0.83. If these estimates are regarded as sufficiently close to unity to cause bias it means that our $\mathrm{H}$ statistics are smaller in absolute value than they should be. Given that our $\mathrm{H}$-statistics are negative this suggests that they are not as negative as they should be. This can only reinforce our conclusion of a negative $\mathrm{H}$-statistic. It also means that the test statistic for the null hypothesis that the $\mathrm{H}$-statistic is equal to one may not be as negative as it should be and it may be that our failure to reject this hypothesis for the equation where $L N(I N T)$ is the dependent variable is due to this bias. Hence, to the extent that our results are subject to such bias they serve to reinforce our inference that the Vietnamese banking system is monopolistic.

The model with the dependent variable $L N(R E V)$ is reported in column 2 of Table 4 . The H-statistic is negative (-1.28) and is not significantly different from zero however it is significantly different from one.

\footnotetext{
${ }^{16}$ Goddard and Wilson (2009, p. 2285) suggested that the test for the null of the H-statistic being equal to unity will be oversized (suggesting that the null hypothesis will be rejected too often) when the true value of $\delta_{7}$ is close to one. This is because they only consider the situation when the sum of the input price coefficients, $\delta_{1}+\delta_{2}+\delta_{3}$, is positive. However, when this sum is negative, as is the case for our estimates, the test will not reject the null as often as it should (because the H-statistic will not be as negative as it should be).
} 
This equation suggests that the Vietnamese banking system is monopolistic over the period 1999 and 2009. Regarding the input price coefficients, the logarithm of interest expense per total funds is negative and significant while personal expense per person and capital expense per fixed asset are insignificant. $\mathrm{LN}(\mathrm{BR})$ is positive and significant. All other variables (except the intercept and lagged dependent variable) are insignificant.

The model where the dependent variable is $L N(I N T)$ is reported in column 3 of Table 4 . The H-statistic is negative $(-2.98)$ which, as is the case when $L N(R E V)$ is the dependent variable also indicates that Vietnamese banking system is monopolistic. However, because the H-statistic is not significantly different from either one or zero this statistic is not well determined and suggests caution with this interpretation. Nevertheless, since the point estimate of the $\mathrm{H}$-statistic is negative and because the model with LN(REV) is well determined and clearly negative, we believe that the overall conclusion of a monopolistic Vietnamese banking system over the period 1999 to 2009 is convincing.

We recall that the favoured models from Table 3 (that exclude assets and include lagged input prices) suggest that the Vietnamese banking system is in monopolistic competition. However, these models exclude a statistically significant lagged dependent variable and are therefore not valid. When the statistically significant lagged dependent variable is included, as is done in Table 4, the results suggest that the Vietnamese banking system is monopolistic. Hence, we have demonstrated that not accounting for this significant lagged dependent variable will bias the results and lead to inferring monopolistic competition when the banking system is monopolistic.

\section{Conclusion}

In this paper, the Panzar-Rosse model has been applied in order to investigate the degree of competition faced by cooperative financial institutions in Vietnam. Our paper makes the following contributions to the literature. First, our results are based upon the largest sample both in terms of the number of banks and total sample size compared to any previous study of non-structural models in the Vietnamese banking system and ours is the first to clearly isolate the market structure for Vietnam from other countries. Second, this study also extends the previous literature by considering new additional variables. Environmental factors such as total assets, capital/assets, loans/deposits and the number of branches that are incorporated in our models have not been employed in previous studies of Vietnam. 
Further, we use four different dependent variables to provide comparative inference. Third, this is also the first study that considers the exclusion of assets (to avoid specification bias) and the inclusion of lagged input prices (to avoid endogeneity) in a study of the Vietnamese banking system. Fourth, we also compare the OLS/fixed-effects estimators with the GMM estimator (where the model includes a lagged dependent variable) for the Vietnamese banking system and find that choosing the most appropriate (GMM in our case) is important because it substantively changes the conclusions drawn. This represents a further novelty of our paper. The favoured OLS/fixed effect estimators suggest that the Vietnamese banking system is in monopolistic competition. However, incorrectly including assets and/or current input prices can affect the results and, in some cases, lead to the erroneous conclusion that the Vietnamese banking system is perfectly competitive. Furthermore, we found that accounting for a significant lagged dependent variable, as is achieved when using the GMM estimator, indicates that the Vietnamese banking system is monopolistic. Hence, not accounting for significant dynamics also biases inference. Our results illustrate the importance of correctly specifying the model to achieve the most reliable inference because all 3 market structures (perfect competition, monopolistic competition and monopoly) can be inferred depending upon which model is used. The significant coefficient of the lagged dependent variable confirms the dynamic character of the model specifications for Vietnamese banks. Using the correctly specified model that uses lagged input prices, excludes assets and includes a lagged dependent variable suggests that the whole Vietnamese banking system is characterised by monopoly from 1999 to 2009.

Our results for Vietnam are different from those for the EU countries found in previous works. Our results show that the Vietnamese banking system is monopolistic while other studies found that European banking sectors operate under conditions of monopolistic competition (Molyneux et al., 1994; Bikker and Groeneveld, 2000; Bikker et al., 2006a, 2006b and Bikker and Spierdijk, 2009). In Vietnam, three out of five state owned commercial banks accounted for 45 per cent of customer deposits, 41 per cent of total assets and 51 per cent of customer loans of the banking system in 2009 (see Nguyen and Stewart, 2013). From 1999 to 2009, five state owned commercial banks still dominated the whole banking system although non-state owned commercial banks exhibited greater overall technical efficiency than state owned commercial banks (see Stewart et al., 2016).

A number of policy implications arise out of this paper. We argue that the monetary policy tightening that began in 2008 had a large impact on the banking system in terms of compulsory reserves, loans and 
deposits. Generally, the banking system encounters many difficulties, resulting from the loss of balance in the source and use of funds, and the rapid increase in credit growth (see Nguyen and Stewart, 2013). Hence, macroeconomic policies from the State Bank of Vietnam should be used to simultaneously meet the high demand of loans from the public and to control rising inflation brought about by a rapid increase in credit growth. We also find that banks that open more branches increase their revenue. Thus, the State Bank of Vietnam should consider introducing policies to enhance the development of commercial banks to raise competition and revenue in the banking system.

\section{References}

Arellano, M. and Bond, S. (1991). Some tests of specification of panel data: Monte Carlo evidence and an application to employment equations. Review of Economics Studies, 58, 277-297.

Bikker, J.A. and Bos, J.W.B. (2008). Bank performance. Abingdon: Routledge.

Bikker, J.A. and Groeneveld, J.M. (2000). Competition and concentration in the E.U. banking industry. Kredit and Kapital, 33, 62-98.

Bikker, J.A. and Spierdijk, L. (2009). Measuring and explaning competition in the financial sector. Utrecht School of Economics Working Paper 09-01.

Bikker, J.A., Spierdijk, L. and Finnie, P. (2006a). Misspecification in the Panzar-Rosse model: Assessing competition in the banking Industry. DNB Working Paper 114.

Bikker, J.A., Spierdijk, L. and Finnie, P. (2006b). The impact of bank size on market power. DNB Working Paper 120.

Blundell, R. and Bond, S. (1998). Initial Conditions and Moment Restrictions in Dynamic Panel Data Models. Journal of Econometrics, 87, $111-143$.

Claessens, S. and Laeven, L. (2004). What drives bank competition? Some international evidence. Journal of Money, Credit and Banking, 36(3), 563-583.

DeBandt, O. and Davis, P. (2000). Competition, contestability and market structure in European banking sectors on the eve of EMU. Journal of Banking and Finance, 24, 1045-1066.

Dufhues, T. (2003). Transformation of the financial system in Vietnam and its implications for the rural market - An updated. Journal of Institutional Innovation, 7, 29-41.

Gelos, R.G. and Roldos, J. (2004). Consolidation and market structure in emerging market banking systems. Emerging Markets Review, 5, 39-59. 
Goddard, J.A. and Wilson, J.O.S. (2009). Competition in banking: A disequilibrium approach. Journal of Banking and Finance, 33, 2282-2292.

Goddard, J.A., Molyneux, P. and Wilson, J.O.S. (2001). European banking: Efficiency, technology and growth. Chichester: John Wiley \& Sons, Ltd.

Lloyd-Williams, M., Molyneux, P. and Thornton, J. (1994). Market structure and performance in Spanish banking. Journal of Banking and Finance, 18, 433-443.

Matousek, R., Nguyen, T.N. and Stewart, C. (2013). Market structure of the banking sector: Evidence from a developing country. London: Kingston Working paper.

Matthews, K., Murinde, V. and Zhao, T. (2007). Competitive conditions among major British banks. Journal of Banking and Finance, 31, 2025-2042.

Molyneux, P. and Forbes, W. (1995). Market structure and performance in European banking. Applied Economics, 27, 155-159.

Molyneux, P., Lloyd-Williams, D.M. and Thornton, J. (1994). Competitive conditions in European banking. Journal of Banking and Finance, 18, 445-459.

Nathan, A. and Neave, E.H. (1989). Competition and contestability in Canada's financial system: Empirical results. Canadian Journal of Economics, 22, 576-594.

Nguyen, T.N. and Stewart, C. (2013). Concentration and efficiency in the Vietnamese banking system between 1999 and 2009: A structural model approach. Journal of Financial Regulation and Compliance, 21(3), 269-283.

Panzar, J.C. and Rosse, J.N. (1987). Testing for monopoly equilibrium. The Journal of Industrial Economics, 35(4), 443-456.

Roodman, D. (2009). How to do xtabond2: An introduction to "Difference" and "System" GMM in Stata. The Stata Journal, 9(1), 86-136.

SBV. (2005). Annual Report. Hanoi: SBV.

SBV. (2008). Annual Report. Hanoi: SBV.

SBV. (2009). Annual Report. Hanoi: SBV.

Shaffer, S. (1982). A non-structural test for competition in financial markets. Bank Structure and Competition (pp. 225-243). Chicago: Federal Reserve Bank of Chicago.

Shaffer, S. (2004). Pattern of competition in banking. Journal of Economics and Business, 54, 287-313.

Stewart, C., Matousek, R. and Nguyen, T.N. (2016). Efficiency in the Vietnamese banking system: A DEA double bootstrap approach. Research in International Business and Finance, 36, 96-111.

VCSC. (2008). Vietnam banking system: Reality and forecast. Ho Chi Minh city: VCSC. 
WB. (2008). Taking stock: An update on Vietnam's recent economic development. Hanoi: Annual

\section{Consultative for Vietnam.}

Table 1: The number of commercial banks from 1990 to $2009^{17}$

\begin{tabular}{l|rrrrr}
\hline \multicolumn{1}{c|}{ Type of banks } & 1990 & 1995 & 2000 & 2005 & 2009 \\
\hline \hline State owned commercial banks & 4 & 4 & 5 & 5 & $\mathbf{5}$ \\
Non-state owned commercial banks & & & & & \\
Joint stock commercial banks & 0 & 36 & 39 & 37 & $\mathbf{3 7}$ \\
Branches of foreign banks & 0 & 18 & 26 & 31 & $\mathbf{4 8}$ \\
Joint venture commercial banks & 0 & 4 & 5 & 5 & $\mathbf{6}$ \\
Foreign commercial banks & 0 & 0 & 0 & 0 & $\mathbf{5}$ \\
\hline Total & 4 & 62 & 75 & 78 & 101 \\
\hline \hline
\end{tabular}

Sources: Dufhues (2003), SBV (2005, 2008, 2009) and VCSC (2008).

Table 2: Data on loans, assets, deposits, capital and non-performing loans of the Vietnamese commercial banks (state owned commercial banks and non-state owned commercial banks) from 1999 to 2009 (Unit: 1,000 Vietnamese Dong)

\begin{tabular}{c|c|rrrrr}
\hline \hline Year & Bank type & Loans & Assets & Deposits & Capital & $\begin{array}{c}\text { Non-performing } \\
\text { loans }\end{array}$ \\
\hline \hline \multirow{2}{*}{1999} & SOCBs & $72,142,247$ & $134,890,858$ & $87,326,439$ & $5,468,772$ & $10.78 \%$ \\
& Non-SOCBs & $35,899,360$ & $58,871,839$ & $30,293,986$ & $9,284,887$ & N/A \\
\hline \multirow{2}{*}{2000} & SOCBs & $108,422,565$ & $200,433,947$ & $127,033,459$ & $5,413,772$ & $10.02 \%$ \\
& Non-SOCBs & $41,231,535$ & $75,856,994$ & $43,321,781$ & $10,139,627$ & $9.42 \%$ \\
\hline \multirow{2}{*}{2001} & SOCBs & $135,647,621$ & $247,151,769$ & $160,738,302$ & $5,421,134$ & $8.83 \%$ \\
& Non-SOCBs & $45,466,715$ & $88,614,974$ & $51,759,565$ & $10,953,034$ & $7.81 \%$ \\
\hline \multirow{2}{*}{2002} & SOCBs & $165,921,733$ & $286,860,920$ & $189,313,313$ & $10,061,113$ & $7.62 \%$ \\
& Non-SOCBs & $55,296,802$ & $102,590,591$ & $63,658,203$ & $11,152,585$ & $5.41 \%$ \\
\hline \multirow{2}{*}{2003} & SOCBs & $214,481,096$ & $367,813,825$ & $237,485,761$ & $14,516,916$ & $5.13 \%$ \\
& Non-SOCBs & $74,068,790$ & $130,337,981$ & $79,255,399$ & $12,398,334$ & $3.57 \%$ \\
\hline \multirow{2}{*}{2004} & SOCBs & $295,738,175$ & $468,341,918$ & $311,681,861$ & $17,362,940$ & $2.92 \%$ \\
& Non-SOCBs & $103,563,777$ & $183,404,071$ & $109,681,322$ & $14,860,054$ & $2.26 \%$ \\
\hline \multirow{2}{*}{2005} & SOCBs & $380,850,503$ & $603,540,889$ & $406,957,181$ & $18,429,980$ & $3.81 \%$ \\
& Non-SOCBs & $143,449,737$ & $261,307,537$ & $144,499,838$ & $20,009,805$ & $1.42 \%$ \\
\hline \multirow{2}{*}{2006} & SOCBs & $435,695,864$ & $731,657,400$ & $524,533,245$ & $18,777,200$ & $3.19 \%$ \\
& Non-SOCBs & $212,097,344$ & $430,755,234$ & $229,411,786$ & $35,578,494$ & $1.29 \%$ \\
\hline \multirow{2}{*}{2007} & SOCBs & $564,677,195$ & $904,004,852$ & $652,913,108$ & $30,091,997$ & $1.87 \%$ \\
& Non-SOCBs & $420,184,441$ & $903,961,807$ & $456,920,152$ & $66,066,418$ & $0.94 \%$ \\
\hline \multirow{2}{*}{2008} & SOCBs & $671,732,670$ & $1,078,729,233$ & $775,560,005$ & $39,279,325$ & $2.47 \%$ \\
& Non-SOCBs & $534,692,051$ & $1,097,675,565$ & $593,628,040$ & $103,923,040$ & $1.62 \%$ \\
\hline \hline \multirow{2}{*}{200918} & SOCBs & $903,718,777$ & $1,320,357,324$ & $869,410,909$ & $61,293,664$ & N/A \\
& Non-SOCBs & $560,883,667$ & $1,210,244,318$ & $680,665,451$ & $115,192,318$ & N/A \\
\hline \multirow{2}{*}{ NOCB }
\end{tabular}

Note: SOCBs: State owned commercial banks; Non-SOCBs: Non-state owned commercial banks. Sources: SBV (2009); Financial statements of 48 Vietnamese commercial banks.

\footnotetext{
17 Beside these commercial banks, there are also the Social Policy Bank and Vietnam Development Bank which are operating as non-profit institutions.

${ }^{18}$ We could not collect data of the North Asia Commercial Bank and Vinasiam Bank in 2009.
} 
Table 3: Fixed-effects estimations for the full sample (Observations $=376$ )

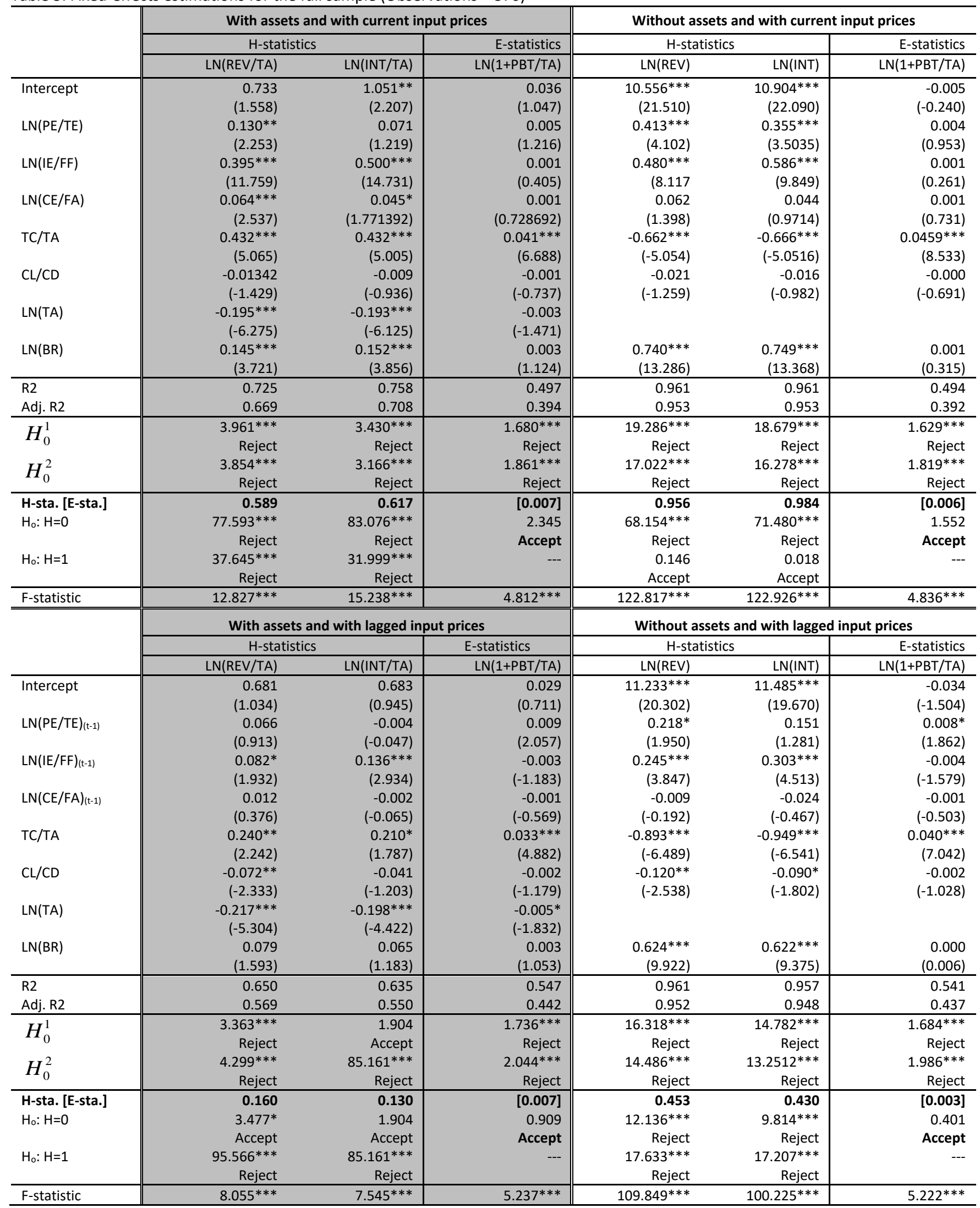

Note: $R 2$ denotes the coefficient of determination, Adj. $R 2$ the adjusted coefficient of determination, $H_{0}^{1}$ is an F-test for the significance of cross-sectional fixed-effects, $H_{0}^{2}$ is an F-test for the joint significance of cross-sectional and time-period fixed-effects and F-sta. tests the null that R2 is equal to zero. The variables' coefficients and $t$-statistics (in brackets) are reported in the table; ${ }^{* * *}$ indicates significance at the $1 \%$ level, ** significance at the $5 \%$ level and * significance at the $10 \%$ level. Source for the data are the financial statements of 48 Vietnamese commercial banks. 
Table 4. GMM 1-step system estimator (excluding assets and including lagged input prices) for the full sample

\begin{tabular}{|c|c|c|}
\hline & LN(REV) & LN(INT) \\
\hline L1 LN(REV) & $\begin{array}{c}0.7498^{* * *} \\
(9.705)\end{array}$ & \\
\hline L1 LN(INT) & & $\begin{array}{c}0.8274^{* * *} \\
(8.215)\end{array}$ \\
\hline L1 LN(PE/TE) & $\begin{array}{c}-0.0755 \\
(-0.5435)\end{array}$ & $\begin{array}{l}-0.1709 \\
(-1.201)\end{array}$ \\
\hline L1 LN(IE/FF) & $\begin{array}{c}-0.2404 * * * \\
(-3.077)\end{array}$ & $\begin{array}{c}-0.3327^{* * *} \\
(-3.651)\end{array}$ \\
\hline L1 LN(CE/FA) & $\begin{array}{c}-0.005 \\
(-0.146)\end{array}$ & $\begin{array}{c}-0.0114 \\
(-0.3096)\end{array}$ \\
\hline $\mathrm{TC} / \mathrm{TA}$ & $\begin{array}{c}-0.1286 \\
(-0.6753)\end{array}$ & $\begin{array}{c}-0.03 \\
(-0.1454)\end{array}$ \\
\hline $\begin{array}{l}\mathrm{CL} / \mathrm{CD} \\
\mathrm{LN}(\mathrm{TA})\end{array}$ & $\begin{array}{c}-0.0338 \\
(-0.7207)\end{array}$ & $\begin{array}{c}-0.0061 \\
(-0.1262)\end{array}$ \\
\hline $\mathrm{LN}(\mathrm{BR})$ & $\begin{array}{c}0.2069 * * * \\
(2.89)\end{array}$ & $\begin{array}{c}0.1441 \\
(1.62)\end{array}$ \\
\hline constant & $\begin{array}{c}2.659^{* * *} \\
(3.964) \\
\end{array}$ & $\begin{array}{l}1.925^{* *} \\
(2.182) \\
\end{array}$ \\
\hline $\begin{array}{l}\text { Instruments } \\
\text { Groups }\end{array}$ & $\begin{array}{l}34 \\
46 \\
\end{array}$ & $\begin{array}{l}34 \\
46 \\
\end{array}$ \\
\hline $\begin{array}{l}A R(1) \\
A R(2) \\
\text { Hansen }\end{array}$ & $\begin{array}{c}0.005^{* * *} \\
0.715^{* * *} \text { Valid } \\
0.110^{* * *} \text { Valid }\end{array}$ & $\begin{array}{c}0.009^{* * *} \\
0.757^{* * *} \text { Valid } \\
0.107^{* * *} \text { Valid }\end{array}$ \\
\hline $\mathrm{H}_{\mathrm{O}}$ period $\mathrm{FE}$ & $\begin{array}{c}130.87^{* * *} \\
{[0.0000]} \\
\text { Reject }\end{array}$ & $\begin{array}{c}169.11^{* * *} \\
{[0.0000]} \\
\text { Reject }\end{array}$ \\
\hline $\begin{array}{l}\text { L1 OLS } \\
\text { L1 period FE }\end{array}$ & $\begin{array}{l}0.8256 \\
0.7168 \\
\end{array}$ & $\begin{array}{l}0.8420 \\
0.7642\end{array}$ \\
\hline H-statistic & -1.2825 & -2.9842 \\
\hline $\mathrm{H}=0$ & $\begin{array}{c}-1.1217 \\
\text { Accept }\end{array}$ & $\begin{array}{c}-1.0133 \\
\text { Accept }\end{array}$ \\
\hline $\mathrm{H}=1$ & $\begin{array}{c}-2.000 * * * \\
\text { Reject }\end{array}$ & $\begin{array}{c}-1.3529 \\
\text { Accept }\end{array}$ \\
\hline $\begin{array}{l}\text { Wald test } \\
\text { Obs. }\end{array}$ & $\begin{array}{c}12389.79 \\
327\end{array}$ & $\begin{array}{c}13839.51 \\
327\end{array}$ \\
\hline
\end{tabular}

Note: Coefficients, $t$-statistics (round brackets) and probabilities (square brackets) are reported in the table; *** significant at the $1 \%$ level, ** significant at the $5 \%$ level, * significant at the $10 \%$ level. Sources: Financial statements of 48 Vietnamese commercial banks from 1999 to 2009 . Time dummy variable are included in the estimated models, however, we do not report the coefficients of the variables to save space. 